Miscellanées

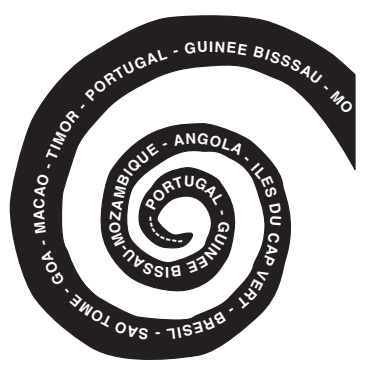




\section{THE WORLDS WHICH THE PORTUGUESE, THE RUSSIANS, AND THE TURKS GREATED: EMPIRES ON EUROPE'S PERIPHERY*}

The revealing analogies among the Portuguese, Russian, and Turko-Ottoman empires add analytical depth to our understanding of the evolution of modern world-system. The empires emerged simultaneously with capitalism and equally relied on the new power techniques of gunpower, bureaucracy, state control over trade, and official religion. Starting from the geopolitical margins of Anatolia, the Pyrenees, or Russian forests, the new empires soon achieved tremendous territorial gains and wealth. But after their first century of success, these empires came under the penetrating pressures of emergent capitalist forces (the Netherlands and later England).

The empires reacted by selectively adopting the organizational and technological innovations of capitalism in the bouts of Absolutist reforms under Peter I, Pombal, or during the Tanzimat period. All three empires underwent another wave of modernizing efforts through the constitutionalist revolutions in 1905-1910 that nonetheless failed to prepare them for the military catastrophe of 1914. The developmentalist dictatorships of Salazar, Atatürk, and Stalin, for all their ideological differences, equally sought to strengthen the production bases under the conditions of state direction and economic autarchy. The global wave of democratic rebellions in 1968 undercut all three versions of developmentalism pushing the bureaucratic and capitalist elites in all three states to seek the preservation of their positions through European integration - whose outcome remains to be seen.

\section{Ces mondes que les Portugais, les Perses et les Turcs ont créés: des empires à la périphérie de l'Europe}

La mise en évidence des analogies entre les empires portugais, russe et turc ottoman permet d'approfondir notre compréhension de l'évolution de l'organisation mondiale contemporaine. L'émergence des empires s'est faite simultanément à celle du capitalisme, et ils ont reposé de la même façon sur les nouvelles techniques de pouvoir que sont la force des armes, la bureaucratie, le contrôle de l'État sur le commerce et la religion officielle. Partant des frontières géopolitiques de l'Anatolie, des Pyrénées ou des forêts de Russie, les nouveaux empires ont très vite atteint une expansion territoriale et une richesse considérable. Pourtant, après un premier siècle couronné de succès, ils ont subi la pression envahissante des puissances capitalistes émergentes (les Pays-Bas et, plus tard, l'Angleterre).

Ces empires ont réagi en adoptant de façon sélective les innovations techniques et organisationnelles du capitalisme au moment des réformes absolutistes de Pierre $I^{\text {er }}$, de Pombal, ou pendant la période du Tanzimat. Ils ont tous trois connu une autre vague d'efforts de modernisation à travers les révolutions constitutionnelles de 1905-1910 qui ne les ont pourtant pas préparés à la catastrophe

* This article has been first published under the title "Some Ideas about Empires on Europe's Periphery (The Worlds the Portuguese, the Russians, and the Turks Created)" in the Russian journal Social Evolution and History (Volgograd, Uchitel), VI(1), March 2007: 146-154. Lusotopie thanks Social Evolution and History for permission. 
militaire de 1914. Les dictatures développementalistes de Salazar, Atatürk et Staline, malgré toutes leurs différences idéologiques, s'efforçaient de la même façon de renforcer les bases de production dans des conditions de direction de l'État et d'autarcie économique. La vague mondiale de rébellions démocratiques de 1968 a miné ces trois versions du développementalisme, poussant les élites bureaucratiques et capitalistes dans ces trois États à chercher à préserver leur position à travers l'intégration européenne - dont le résultat reste à voir.

\section{Os mundos que os portugueses, os russos e os turcos criaram: impérios na periferia da Europa}

O evidenciar das analogias entre o império português, russo e turco otomano dá uma maior profundidade analítica à nossa compreensão da evolução do sistema mundial contemporâneo. Os impérios formaram-se simultaneamente com o capitalismo mas apostando também nos novos poderes técnicos das armas de fogo, na burocracia, no controlo do estado sobre o comércio, assim como na religião oficial. Desde as margens geopolíticas de Anatólia, dos Pirenéus, ou das florestas russas, os novos impérios conquistaram rapidamente um território imenso e tremendas riquezas. Mas após o seu primeiro século de êxitos, esses impérios foram submetidos à crescente pressão das forças capitalistas emergentes (os Países Baixos e mais tarde a Inglaterra).

Reagiram adoptando, de forma selectiva, as inovações do capitalismo ao nível da organização e da tecnologia durante o período das reformas absolutistas sob o comando de Pedro $\mathrm{I}^{\circ}$, do marquês de Pombal ou durante o período do Tanzimat. Mais tarde, os três tiveram que suportar outra vaga de esforços de modernização com as revoluções constitucionais entre 1905-1910, que no entanto falhou no que diz respeito à preparação à catástrofe militar de 1914. As ditaduras desenvolvimentistas de Salazar, Atatürk e Estaline, apesar de suas diferenças ideológicas, procuraram fortalecer as bases de produção em condição de supervisão do estado e de autarcia económica. A onda global de revoltas democráticas, em 1968, reduziu o peso dessas três versões de desenvolvimentismo, ao empurrar as elites burocráticas e capitalistas desses três estados para uma procura de preservação das suas posições através da integração europeia - cujas consequências permanecem por definir.

$\mathrm{T}$ he reigning confusion in the attempts to theorize empires stems from overgeneralization. Empires are simply the medium-run successful result of power strategy which Giovanni Arrighi (1994) called territorialism. This strategy was typically pursued in past epochs by agrarian-coercive apparatuses, otherwise called patrimonial or pre-modern states. The main story during the 'Long Sixteenth Century' (in Fernand Braudel's estimate, roughly from 1450 to 1650) was not the emergence of capitalism but rather the successful expansion of updated agrariancoercive states, or in William McNeill's expression the gunpowder empires (1989), across the central zones of Afro-Eurasian ecumene, from the Sea of Japan all the way to the Iberian peninsula in the West. Among these new monsters were the territorial entities built by the Portuguese, Muscovite Russians, and the Ottoman Turks. After the foundational periods of epic success, all three empires became among the first to come under the pressure of another species in the evolution of social power - the capitalist organizations of Western Europe. Ever since then, all three imperial trajectories have been developing largely in response to the 
expansion of the capitalist networks of trade, innovation, and geopolitics. During this period, Portugal, Turkey, and Russia experienced many similar dilemmas, deployed similar strategies, and went through roughly similar phases of crisis and adaptation.

All three territorialist power organizations (i.e. empires) first tried to fall back on their original glorious models, which after periods of crisis they had to dump more or less violently and instead embrace imitative absolutist reforms; all three to various degree of success tried to profit from the nineteenth-century capitalist globalization; and all three tried to prove their worth by engaging in the First World War. Since the late 1920s, Portugal, Russia, and Turkey pursued the strategies of autarchy and dictatorial modernization. All three former imperial states eventually tried to trade their redundant geopolitical status for the admission into the capitalist European Union. Their former imperial possessions, however, slid mostly into the periphery.

I. In materialist terms, empires might be better conceptualized as large power platforms. Their geopolitical and ideological morphology derived from the strategy of territorial control over tributary populations (Arrighi 1994; Collins 1999). Their socioeconomic metabolism was coercive redistribution (Polanyi 1968) of staple finance which, in an evolutionary trend, tended to be replaced by the monetized forms of wealth finance (Johnson \& Earle 2000).

II. The historical recurrence of imperial form cannot be isolated from the evolutionary diversity of chiefdoms and states (Johnson \& Earle 2000). The larger supra-state units commonly called empires, periodically emerged from the clusters of states found across Afroeurasia as well as the pre-contact Americas. Following the geopolitical regularities of overextension and the emergence of dangerous marchlanders (Collins 1999), empires could collapse back into warring states and chiefdoms.

III. The sharp dichotomy between empires and nation-states based on the opposition of autocracy versus democratic citizenship, however, is an ideological artifact. Analytically, we might still wish to keep the traditional agrarian-coercive empires separate from the modern colonial empires whose governing logic was capitalist (Wallerstein 1989). Empirically, such separation appears more difficult. Until quite recent times, the modern capitalist agencies in the peripheral zone could enjoy the advantage of skimming profits from the globally-extended political economy superimposed upon the local subsistence economies without incurring the full costs of political control and social (and ecological) reproduction. The Netherlands, England, or France were capitalist nation-states in Europe - while at the same time operating overseas as territorialist empires (Arrighi 1994). Take the English East India Company that had inherited from the Mughals an extensive 'root system' for collecting agrarian tribute.

IV. In world-historical perspective (Braudel 1981-1984; McNeill 1989), we must recognize that, in fact, the so-called Long Sixteenth Century (the 1450s-1640s) was the founding epoch of massive agrarian-coercive empires. Capitalism so far remained limited to the part of Western Europe which only eventually would become the core of modern world-system. Elsewhere, the main story of the epoch was the growth of Ming and Manchu empire in China; Japan's consolidation resulting in the Tokugawa shogunate; the Mughal conquest of north-central India; 
the Shia Islamic reformulation of Iranian state under the Safavis; the rebirth of eastern Roman Empire/Byzantium under the Ottoman sultans; the completion of Iberian Catholic reconquista; or the geopolitical breakthrough achieved by Muscovy in the challenging northern zone hitherto barely controlled by any state.

V. The near simultaneous arrival of these empires was evidently related to the military revolution of gunpowder and new infantry (McNeill 1984; Tilly 1992). The trademark of new statehood were the arquebuseiros, Russian streltsy, or Turkish janissaries, or yeni cheri - literally, the new infantry. But the new imperial organization also marked the high point in the evolution of other 'sources of social power' (Mann 1986) such as imperial ideology (better called the world-imperial religions), state-regulated trade, and bureaucratic organization. The result was an awesome geographical extent and sheer concentration of power in the hands of rulers. Hardly by coincidence, among the most familiar faces of the epoch we find the religious despots like Lord Hideyoshi, shah Ismail Safavi, sultan Selim the Grim, Carlos V and Philippe II, Ivan the Terrible, or Aurangzeb who attempted to roll back the official tolerance of earlier Mughals.

\section{Origin and Evolution of Portuguese, Ottoman and Russian empires}

I. The origins of Portuguese, Ottoman, and Russian empires pre-date the triumph of European capitalism. Subsequently they have long existed alongside capitalism while being increasingly penetrated and incorporated into the global capitalist networks. A systematic comparison of three empires might illuminate the formative processes of our world while keeping our analyses on firmer grounds than the notions of cultural specificity.

II. The fall of Constantinople in 1453, the racketeering naval domination established in the Indian ocean by the navies of Vasco da Gama and Affonso de Albuquerque in the early 1500s, or the Muscovite forceful extension of Russian heartland into the Great Steppe and Siberia in the 1550s-1640s were all the triumphs of superior guns. The geopolitical vectors of three empires were predetermined by the combinations of traditional trade and migration networks with the ideologically construed horizons. All three began as minor marchlander states aggressively expanding, respectively, from the interior of Anatolia into the areas long unified and exploited by the Romans and Arabs; from the marginal status of the 'Atlantic balcony' proceeding by a daringly inventive route to connect with the fabled markets of the East; and by following in reverse direction the old pathways of nomadic migrations and attacks all the way back to Mongolia. The tribute acquired through successful expansion fed the imperial grandeur and helped to establish powerful states.

III. Portugal, for the obvious reasons of geographical and cultural proximity, was the first to succumb to the Atlantic capitalism. Condemning in the 1540s the moral corruption and hedonism of his times, a Portuguese Catholic polemicist bitterly observed: "Lisbon is just the mouth gobbling the riches of the Indies; but the stomach is in the Flanders" (Godinho 1962: 173). In fact, the maritime expansion of Portugal (as well as Spain) from the outset was financed by the cosmopolitan diaspora of Genoese bankers (Arrighi 1994). Subsequently Portugal, which was never a significant military power, fell into the durable pattern of dependency. 
After regaining sovereignty from Spain in 1640, Portugal essentially leased its impossibly far-flung imperial possessions to the English in exchange for protection and a junior share of profits. Portugal's turn to show some assertiveness would not arrive until the British Empire entered its own terminal crisis in the 1930s (Anderson 1974).

IV. By contrast, Turkey and Russia, both being massive land-based empires and so far less dependent financially, could afford a considerably higher degree of resilience. Already in the 17th century both states felt beleaguered by the capitalist West in trade and military technology as well as ideologically. Their first response, not unlike other empires in comparable situations, was the conservative reaffirmation of Islamic caliphate ideology by the Ottoman rulers and the Orthodox Church reform in Muscovy. This went along with the attempts to harshly control all communications with the West.

V. Still, the gap in military capacity vis-à-vis the capitalist West grew threatening. Russian monarchy under Peter I (1690s-1720s) became the first to attempt the emulative absolutist reforms. The state had to be split from the top in order to use the newly reformed part to cruelly suppress the resistances of old military and political elites: the streltsy were executed, the church lost autonomy, the new Westernized gentry was implanted over the heads old nobility, not to mention the move of imperial capital to the Baltic swamplands. The pattern of splitting the Russian state in order to use one part as lever against the other would reemerge again in the revolution and Civil war of 1917-1920 and during Gorbachev's perestroika in 1985-1991. Portugal in the mid-eighteenth century registered a similar albeit less ambitious bout of absolutist reforms under Marquis de Pombal. The Turks would take another century to begin catching up after the Tanzimat decrees of the 1830s.

VI. The further and arguably the biggest achievement of tsar Peter's reform was at the Turkish expense. During the 18th century new Russian armies eliminated the perennial threat of the Crimean Tatar slave raiding and opened northern access to the Black sea. This military advance secured one of the richest agricultural landscapes in the world: Novorossiya (New Russia, today mostly in Ukraine). What followed was the grandest feudal colonization in history which accorded to the reign of tsarina Catherine II the title of the Golden Age of Nobility (Anderson 1974). The Turks, in the meantime, were paying the price of their past imperial grandeur - the accumulated weight of the Ottoman institutions and official ideology delayed Westernizing reforms. The realm nearly disintegrated into provincial chiefdoms which greatly facilitated the penetration of Western capitalist trade.

VII. Coercion was, of course, integral to agrarian empires which were, in the main, siphons for sucking tribute (Stavrianos 1982). Yet there also seems to be a lot to the old argument that coercive intensification of peripheral agriculture developed in response to the external capitalist pressures. Historians subjected this argument to two empirical criticisms doubting, first, the uniformity of increases in the expropriation of rural labor and, secondly, demanding to show the causal mechanism leading to such outcome. This debate can be better focused if not settled by introducing two variables: the effectiveness of coercion and the relative commercialization that in the past very much depended on the maritime access to market profits from agricultural exports and the importation of luxury goods 
for the elite status consumption. On a balance, the effective reach of coercion seems the highest across the vast Russian countryside, but it could be more concentrated in the disparate locations where the Portuguese maintained their slave plantations, with the Ottoman realm showing the greatest regional and temporal disparities. Overall, the resulting trend applied to all three empires. Their balance of payments suffered from unequal exchange in the external markets which none of them could control. The imperial realms were drained of investment capitals and entrepreneurial potential for the economic activities other than coercive agriculture and most basic local crafts. In sum, this trend is called underdevelopment. In the meantime, let us note, the traditional imperial strategy of overcoming 'decline' - namely, territorial conquest - was now checked by the geopolitical competition of Western industrial imperialists. (Only the Russians in the 19th century continued to expand, with rapidly decreasing returns, into the harsh landscapes of the Caucasus and Turkistan. The Portuguese claims to the interior of Africa would remain nominal and thus entirely unprofitable until the mid-twentieth century.

VIII. The three far-flung imperial realms contained a lot of geographic 'friction' which was poorly mitigated by the existing communications (Harvey 2003). For this reason they remained polyglot and divided into numerous communities with distinct social institutions and practices. Put differently, the imperial states remained un-national. This statement, however, sounds too sweeping to be a meaningful theoretical generalization. It ignores the fact that old empires, even such splendid as the Roman and Chinese, neither needed nor could afford the intensity of state and market penetration which would culturally homogenize their populations. This does not mean that empires did not pursue their own strategies of homogenization. One was the alliance-building (inseparable from more or less coercive supervision) among the locally ruling elites. Like virtually all states before the advent of modern bureaucracy and instantaneous communications, empires had to rule through the chains of local notables, priests, and other intermediaries (Tilly 1992). The elements within these chains, however, were unified by the hegemonic imperial culture, not least of all the palace culture much of which (palace music, painting, or cuisine) in retrospect would be presented as distinct civilizations. This strength of elite homogenization corresponded quite directly to the prestige of empire eliciting from the provincials the desire to emulate the prestigious lifestyles. This cultural strength, in turn, directly flowed from geopolitical power and prestige (Collins 1999; Johnson \& Earle 2000). The other strategy of imperial cohesiveness was religious policy. The dynamics of conversion to imperial creed (which after the demise of empires could linger as the civilizational afterglow - as in Western Christendom or the Islamic countries) was determined by the interplay of imperial strength and the resilience of pre-dating local institutions. In the Ottoman realm, such institutions could be strong enough to better incorporate them in the structures of rules as autonomous bodies. In Brazil and Africa (much less so in Macao or India) the relatively feeble Portuguese rule could still convert the conquered populations into its creed and language albeit usually in syncretistic forms. On this count, Russia remained somewhere in the middle - turning Russian into lingua franca, which was achieved to a very impressive extent, nonetheless almost never translated into the erasure of non-Russian identities. The prevalent focus 
on post-imperial nationalisms obscures the dynamically complex dualisms of such cultural situations.

\section{The Ghanges in the 20th Gentury}

I. In 1914 the core states of capitalist world-system committed a group suicide. The core's implosion brought down the Russian and Turkish empires in extremely violent ways. The Russian state was put back together by the tightly organized party of intelligentsia who drew their inspiration from German sources - Marx and SPD, but no less from the war economy of general Ludendorff. The combination proved so formidable that Russian empire could be re-established on new foundations for three more generations. Turkey between 1914 and 1923 was bloodily cut to a national state, whose leadership emerged from the ranks of military intelligentsia versed mostly in Durkheim and French republicanism. Portugal, for centuries the safest backwater of Europe, experienced its share of revolutionary turmoil which after 1928 ended, without much terror, in the longlasting reactionary dictatorship. Yet Portugal's Estado Novo, despite the moves to emulate the fascist Italy and Germany, neither dared to unleash a fascist movement nor could gather the requisite organizational capacity. Yet even Portugal obtained in the chaos of the 1914-1945 hegemonic transition its opportunity to become a fairly autonomous state.

II. The paradigmatic anti-imperialist revolts of the 20th century tended to coincide with the centers of former agrarian empires: Russia, Turkey, Spain, China, India, Iran, or even Ethiopia. Evidently, such locations offered richer concentrations of resources for mobilization, including military, and contained the elites who could hope for renewed greatness if they successfully connect with popular resentments and manage to upgrade their states.

III. Analytically, the twentieth-century socialist and nationalist states can be presented as partially overlapping sectors on the same continuum of historical possibilities. Their difference is more in the degree of state's reach than in ideology. When a group of intelligentsia alienated from economic property managed to transform themselves into revolutionary regime and used the state power to bring under government's control all economic assets down to peasant households, the result was called socialism. When state power was taken by the alliance of property owners, lesser officials, and intelligentsia in order to bring under government's control the economic assets of foreign capitalists and the particularly 'unprogressive' classes like clergy and landlords, the outcome would be proclaimed national liberation. In both cases the economic assets accumulated by the newly reinforced government were put into the expansive programs of capital investment. The goal was to rapidly reproduce within the state jurisdiction the industries and education establishment similar to the core Western states.

IV. A successful developmentalist dictatorship, whether communist of nationalist, could maintain the rapid pace of industrialization for two or three decades. After that comes the slow down caused by the maturation of command economy, the passive power obtained by its new proletarians, and the self-encapsulation of mid-ranking bureaucracies. The USSR, Kemalist Turkey, and Portuguese Estado Novo exemplified three different paradigms within the same continuum of 
developmentalist dictatorships. All three industrialized and achieved significant rates of material accumulation first during the autarchic 1930s and still more impressive results in the expansive 1950s-1960s. All three, after industrial spurt, in their own but analytically comparable ways ran into what Peter Evans (1995) calls the pressures to dismantle the developmental state. Portugal and the USSR, both under the strain of colonial defeats, democratized in spectacular fashion. Turkey underwent a series of acute crises which also resulted in the institutionalization of competitive politics. Portugal was the first to completely abandon its imperial pretensions for the sake of rapid integration into the emergent European suprastate. Turkey moved in the same direction, but the Russian future seems more problematic. Did we see the end of imperial trajectories?

March 2007

Georgi M. DERLUGUIAN

Northwestern University (Evanston/Chicago, IL)

\section{References}

Anderson, P. 1974, Lineages of the Absolutist State, London, New Left Books.

Arrighi, G. 1994, The Long Twentieth Century: Money, Power, and the Origins of our Times, London, Verso.

Braudel, F. 1981-1984, Material Civilization and Capitalism, 1450-1800, New York, Harper and Row, 3 vols.

Collins, R. 1999, "Market Dynamics as the Engine of Historical Change", in R. Collins, Macrohistory: Essays in Sociology of the Long Run, Stanford, Stanford University Press: 177-208.

Evans, P. 1995, Embedded Autonomy: States and Industrial Transformation, Princeton, Princeton University Press.

Godinho, V.M. 1962, A Economia dos Descobrimentos Henriquinos, Lisbon, Livraria Sá da Costa. Harvey, D. 2003, The New Imperialism, Oxford, Oxford University Press.

Johnson, A.W. \& Earle, T. 2000, The Evolution of Human Societies: From Foraging Group to Agrarian State, Stanford, Stanford University Press.

Mann, M. 1993, The Sources of Social Power, Cambridge, Cambridge University Press, 2 vols.

MaNeill, W. 1984, The Pursuit of Power: Technology, Armed Force, and Society since AD 1000, Chicago, University of Chicago Press

1989, The Age of Gunpowder Empires, 1450-1800, Washington (DC), American Historical Association.

Polanyi, K. 1968, Primitive, Archaic and Modern Economies, Boston, Beacon Press.

Stavrianos, L.S. 1982, Global Rift: The Third World Comes of Age, New York, Morrow.

Tilly, Ch. 1992, Coercion, Capital, and European States, AD 990-1992, Oxford, Blackwell.

WallersteIn, I. 1989, The Modern World-System Volume III: The Second Era of Great Expansion of the Capitalist World-Economy, 1730-1840s, New York, Academic Press. 